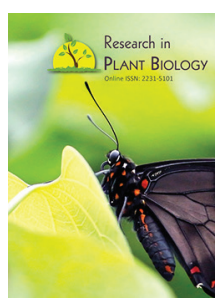

ISSN: $2231-5101$

\title{
Effect of land management on the dynamics of natural regeneration of agroforestry Parkland forest tree species: Case study of Vitellaria paradoxa in Southern Mali (West Africa)
}

\author{
Bokary Allaye Kelly*, Jean-Marc Bouvet ${ }^{2}$ \\ 'Institut d'Economie Rurale, Programme Ressources Forestières, Centre Régional de la Recherche Agronomique de \\ Sikasso, BP 178 Sikasso Mali, ${ }^{2}$ Cirad Forestry Department, "Genetic diversity and breeding of forest tree species" \\ research unit, Campus International de Baillarguet, TA 10C, BP 5035, 34035 Montpellier, France
}

\begin{abstract}
The dynamics of the natural regeneration of Vitellaria paradoxa (karité or shea tree) was studied in southern Mali with the aim of assessing the effect of human practices of land use (forest, fallow). Different categories of regeneration were monitored during three years in forest and fallow stands. The spatial distribution, the density and the growth of the regeneration were studied and stands were compared using SAS's GLM procedure. Time effect and the different interactions were tested using SAS's repeated measures method. The regeneration was differently distributed in the stands. In the fallow stand it occurred across the whole area while in the forest stand it appeared as Patches Under Karité trees (PUK), Patches Under Other tree Species (PUOS) and Patches Out of any Cover (POC). The density of the regeneration was higher in the fallow stand, but the effect of stand was not significant for height growth. In the forest stand, patch effect on measured variables was weak. A significant time effect on height growth was observed and the time* patch interaction was significant also. Variations of density and growth were observed according to year, suggesting high sensitivity of shea tree natural regeneration to varying environmental conditions.
\end{abstract}

*Corresponding Author:

Bokary Allaye Kelly

Email: bokarykelly@gmail.com

KEYWORDS: Fallow, forest, land management, regeneration, parkland, shea tree, sudanian zone, southern Mali

\section{INTRODUCTION}

A sound knowledge of forest regeneration is essential for effective forest management because the regeneration phase will determine to a large extent the nature of subsequent forest composition [1]. The role of natural regeneration in a case of well managed silviculture is to ensure the survival of important tree species such as those of parklands like Vitellaria paradoxa that play important ecological and socioeconomic roles.

Although regeneration processes are well known for temperate and rainforest species $[2,3,4,5]$, little is known in the context of dry ecosystems, especially for African savannah trees species. We investigated the effect of land management mode on the dynamics of natural regeneration of a particular tree species of agroforestry parkland in the Sudano-sahelian zone.

Agroforestry parklands are traditional land-use systems in the Sahelian region of West Africa. In these systems, farmers grow annual crops and scattered trees form an open permanent upper storey [6]. Raison (1988) [7] stated that parklands are the result of a long evolutionary process during which association between natural elements (trees and shrubs conserved, maintained and enhanced because of their utility) and crops happens within a regularly exploited space.

In the Sudano-sahelian zone, two land management modes are usually observed by farmers. The first mode, called here "fallow stand", refers to the field/fallow cycle, i.e. after intense cultivation activities for a given period (as long as the soil is still fertile), these are stopped and land remains unused for any cultivation for many years with the aim of restoring soil fertility (3-4 years or less nowadays, up to 30 years some decades ago).

The second mode, called here "forest stand", refers to a woody stand not used at all or not used for a very long time (over 30 years) for cultivation activities and where the main human activities are habitat, cutting for fuel and small woodcraft, cattle

Copyright: $\odot 2018$ The authors. This article is open access and licensed under the terms of the Creative Commons Attribution License (http://creativecommons.org/licenses/by/4.0/) which permits unrestricted, use, distribution and reproduction in any medium, or format for any purpose, even commercially provided the work is properly cited. Attribution - You must give appropriate credit, provide a link to the license, and indicate if changes were made. 
grazing and harvesting of medicinal plants. As these stands are managed differently, the management mode may affect the structure and dynamics of growing vegetation (natural regeneration), justifying our idea of comparing the fallow and the forest regarding the structure and dynamics of the natural regeneration of Vitellaria paradoxa (karité, or shea tree).

The comparison is rather appealing nowadays because parklands are facing several constraints due to a complex combination of natural, technological, and socioeconomic factors [8] leading to an evident degradation stressed by many authors $[9,10,11,12]$.

The two management modes described above are well representative of farmers' practices in the Sudanian zones of west Africa in general and particularly in southern Mali where this study was conducted. Unfortunately, their impact on the growing tree species was not assessed and this lack of information concerns even the most important parkland tree species. The objective of this study was therefore to compare fallow and forest regarding the dynamics of the natural regeneration of $\mathrm{V}$. paradoxa, a common agroforestry parkland tree species providing high-quality butter used for cooking and in the chocolate, cosmetic and medicinal industries. In addition, V. paradoxa improves the microclimate and soil fertility and branches are used as firewood and for saw logs [13].
We hypothesised that the management mode (fallow or forest) affects the structure and dynamics of the natural regeneration of the shea tree. The main research questions we addressed were: (i) How does land management affect the spatial distribution of the natural regeneration of $\mathrm{V}$. paradoxa? (ii) Does the natural regeneration of $\mathrm{V}$. paradoxa display any particular structure according to land management? (iii) What is the impact of land management on the dynamics (recruitment, growth and mortality) of the natural regeneration of $\mathrm{V}$. paradoxa?

\section{MATERIALS AND METHODS}

\section{Study Site}

The study was carried out at Mperesso in the region of Sikasso in southern Mali (see Map l) in the two stands (fallow and forest) described above. Mperesso is located in the north of the region $\left(12^{\circ} 16^{\prime} 48.00^{\prime \prime N}, 5^{\circ} 19^{\prime} 48^{\prime \prime} \mathrm{W}\right)$. The climate is south Sudanian. For the period 1991 to 2002, the mean annual rainfall was $900.7 \mathrm{~mm}$, with a minimum of $586 \mathrm{~mm}$ and a maximum of $1249 \mathrm{~mm}$.

\section{Experimental Layout of Stands}

A soil study undertaken in July 2004 in the experimental stands revealed that the soil of the forest stand is gravel over cuirass



Map 1: Localisation of the site of Mperesso in southern Mali and layout of parcels 
or sandstone that is not deep, whereas the soil of the fallow stand is ferruginous and tropical over cuirass that is shallow to medium deep [14].

A vegetation study undertaken at the same period in the same stands revealed some differences between the two stands regarding their floristic richness and shea tree density [14]. In the forest stand, 17 forest tree species were inventoried. The density of individuals of height above $1 \mathrm{~m}$ was 1257 stems/ha. The dominant tree species were Acacia macrostachya (23.75\% of the total number of individuals), Combretum fragrans (13.75\%) and Detarium microcarpum (12.5\%). V. paradoxa represents only $3.75 \%$ and the density of adult trees (Girth at Breast Height: $\mathrm{GBH} \geq 20 \mathrm{~cm}$ ) was 17 trees/ha.

In the fallow stand, 21 forest trees species were inventoried. The density was 1686 stems/ha and V. paradoxa is the dominant tree species (17.5\%), followed by Pteleopsis suberosa (15\%) and Guiera senegalensis (13.75\%). Stand characteristics are shown in Table 1 and the distribution of adult trees in the two stands is illustrated in Figure 1.

$€ \mathrm{VMAR}=$ variation of mean annual rainfall; $\mathrm{GBH}=$ girth at breast height

\section{Experimental design}

In each stand, transects of varying length (100 to $150 \mathrm{~m}$ ) were established with respect to parcel size. In the forest stand, ten

Table 1: Characteristics of the stands: areas of the parcels, approximate density and mean girth of adult trees of Vitellaria paradoxa

\begin{tabular}{lccc}
\hline & \multicolumn{3}{c}{$\begin{array}{c}\text { SITE 0F MPERESS0 } \\
\text { VMAR } \alpha=586-1249 \mathrm{~mm}\end{array}$} \\
\hline Stands & Area (ha) & Density $\left(\mathrm{ha}^{-1}\right)$ & Mean GBH (cm) \\
\hline Fallow & 2.1 & 68.1 & 61.10 \\
Forest & 7.4 & 17.7 & 45.94 \\
\hline
\end{tabular}

aVMAR = variation of mean annual rainfall; $\mathrm{GBH}=$ girth at breast height

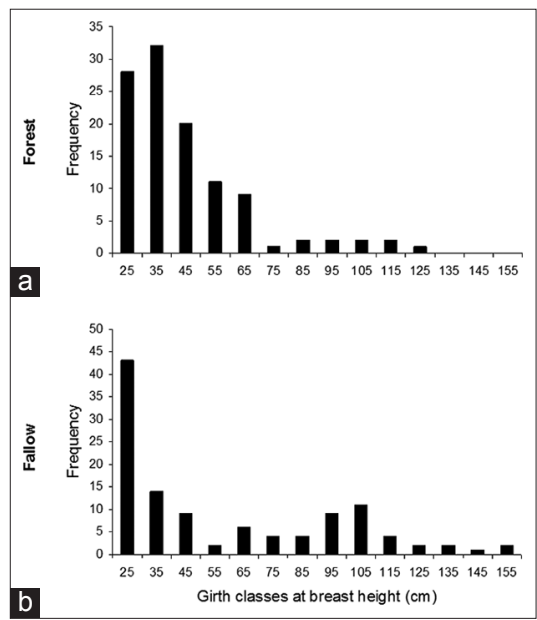

Figure 1: Distribution of adult trees in the forest stand (a) and fallow stand (b) transects were established while four transects were established in the fallow stand. Within each transect, experimental units were defined with respect to the spatial distribution of the natural regeneration of $\mathrm{V}$. paradoxa.

Hence in the forest stand, where the regeneration was distributed as patches, the experimental units are constituted by the patches occurring in the ten transects. The size of an experimental unit therefore depends on the size of the patch encountered. The total area covered by the whole patches of the ten transects was $5000 \mathrm{~m}^{2}$.

In the fallow stand, where the regeneration of V. paradoxa was randomly distributed in the whole parcel, experimental units are constituted by plots of $50 \mathrm{~m}^{2}$. In each of the four transects, five plots were established for a total study area of $250 \mathrm{~m}^{2}$ per transect. The total area covered in this stand was $1000 \mathrm{~m}^{2}$.

\section{Regeneration Study Method}

A preliminary exploration has shown that the natural regeneration of $\mathrm{V}$. paradoxa has different spatial distribution in the forest stand compared to the fallow stand. In the forest stand, regeneration occurs in patches of various types randomly distributed in the stand. We distinguished three types of patches: Patches met Under adult Karité trees (PUK), Patches met Under Other tree Species (PUOS) like Daniellia oliveri, Cordylla pinnata, Terminalia macroptera, and finally Patches Out of any Cover (POC). In the fallow stand, however, regeneration was distributed randomly in the whole stand with varying density across the area.

The natural regeneration (NR) in these two stands was monitored during three successive years (2002 to 2004). For this study, the regeneration was split into four classes described below:

- class 1: concerns all individuals of height (H) less than or equal to $50 \mathrm{~cm}(\mathrm{H} \leq 50 \mathrm{~cm})$; named germinants;

- class 2: concerns individuals with height between $50 \mathrm{~cm}$ and $1 \mathrm{~m}(50 \mathrm{~cm}<\mathrm{H} \leq 1 \mathrm{~m})$; named seedlings;

- class 3: concerns individuals with height greater than $1 \mathrm{~m}$ and girth at breast height (GBH) less than or equal to $10 \mathrm{~cm}$ $(\mathrm{H}>1 \mathrm{~m}$ and $\mathrm{GBH} \leq 10 \mathrm{~cm})$; named saplings;

- class 4: concerns individuals with GBH greater than $10 \mathrm{~cm}$ but less than $20 \mathrm{~cm}(10 \mathrm{~cm}<\mathrm{GBH}<20 \mathrm{~cm})$; named young adults.

Data were collected according to class. The number of germinants (class 1) was counted in each plot or patch. The collar girth (CG) and the height (H) of seedlings (class 2), were measured. For the saplings and young adults (classes 3 and 4), the CG, the GBH and the height were measured.

\section{Data Analysis}

Data were first analysed by testing the effect of studied factors using the SAS GLM procedure for each variable at each time point (year of measurement). The Bonferroni test was performed 
to compare the means. After this univariate analysis procedure, repeated measures analysis was conducted considering the 3 time points ( 3 years of measurement) for testing the effect of time and the interaction time factors. We used the split-plot method of repeated measures analysis [15]. This method of analysis takes into account the fact that the different measurements are just repeated on the same subject (units) at different time points which can be regarded as levels of a factor time. This procedure was used to analyse variables like density and height.

The linear models fitted for these variables were:

- Variable $=$ density

Model 1: $\mathrm{Y}_{\mathrm{ijk}}=\mu+\mathrm{S}_{\mathrm{i}}+\mathrm{C}_{\mathrm{j}}+\mathrm{SC}_{\mathrm{ij}}+\mathrm{T}_{\mathrm{k}}+\mathrm{ST}_{\mathrm{ik}}+\mathrm{CT}_{\mathrm{jk}}+\mathrm{SCT}_{\mathrm{ijk}}$ $+\varepsilon_{\mathrm{ijk}}$

Where $\mathrm{Y}=$ response, $\mu=$ overall mean, $\mathrm{S}_{\mathrm{i}}=$ effect of stand $\mathrm{i}\left(\mathrm{i}=\right.$ forest, fallow), $\mathrm{C}_{\mathrm{j}}=$ effect of category $\mathrm{j}(\mathrm{j}=$ germ, seed, sap, yad), $\mathrm{T}_{\mathrm{k}}=$ effect of time $\mathrm{k}(\mathrm{k}=2002,2003,2004)$, $\mathrm{SC}_{\mathrm{ij}}=$ stand ${ }^{*}$ category interaction, $\mathrm{ST}_{\mathrm{ik}}=$ stand ${ }^{*}$ time interaction, $\mathrm{CT}_{\mathrm{jk}}=$ category $^{*}$ time interaction, SCTijk = stand ${ }^{*}$ category ${ }^{*}$ time interaction, $\varepsilon_{\mathrm{ijk}}=$ error.

- Variable $=$ height

Model 2: $\left.\mathrm{Yj}_{(\mathrm{ik}}\right)=\mu+\mathrm{S}_{\mathrm{i}}+\mathrm{T}_{\mathrm{k}}+\mathrm{ST}_{\mathrm{ik}}+\varepsilon_{\mathrm{j}(\mathrm{ik})}$

Where $\mathrm{Y}=$ response, $\mu=$ overall mean, $\mathrm{S}_{\mathrm{i}}=$ effect of stand $\mathrm{i}$ ( $\mathrm{i}=$ forest, fallow $), \mathrm{T}_{\mathrm{k}}=$ effect of time $\mathrm{k}(\mathrm{k}=2002,2003,2004)$, $\mathrm{ST}_{\mathrm{ik}}=$ stand $^{*}$ time interaction, $\varepsilon_{\mathrm{ijk}}=$ error.

\section{RESULTS}

\section{Density Of The Regeneration of V. Paradoxa}

The univariate analysis at each time showed a significant stand effect ( $\mathrm{P}=0.0009$ to 0.006$)$, a significant category effect $(\mathrm{P}<0.0001)$ and a significant stand ${ }^{*}$ category interaction $(\mathrm{P}<0.0001$ to $\mathrm{P}=0.0003)$. The Bonferroni test showed that for each year, for all categories of NR combined, the density in the fallow stand was significantly higher than that in the forest stand (Table 2).

This analysis also showed a significant category effect. For all stands combined, the density of germinants was significantly higher than those of seedlings, saplings and young adults, these last three categories not being significantly different (Table 3).

Means with the same letter are not significantly different

Repeated measures analysis showed no significant time effect $(\mathrm{P}=0.7104)$. The time ${ }^{*}$ stand interaction $(\mathrm{P}=0.6846)$ and the time ${ }^{*}$ category interaction $(\mathrm{P}=0.8309)$ were also not significant.

Densities observed for the different categories of regeneration in stands and in the types of patch are shown in Figures 2 and 3. The mean density of germinants observed in the fallow stand was higher than that observed in the forest stand (Figure 2a).
Also, the mean density observed for this category in patches under karité (PUK) was higher than that observed in the other types of patch in the forest stand (Figure 2b).

For the other categories of regeneration i.e. seedlings, saplings and young adults, the fallow stand showed higher density than the forest stand for all categories (Figure 3a), and only for seedlings was the density noticeably higher for patches under karité (PUK) compared to the other patches (Figure 3b).

A variation of the density according to year was observed for most regeneration categories, particularly in the fallow stand. The trend of variation was dominated by an increase of the density from 2002 to 2003 followed by a decrease in 2004. This feature was observed for the germinants in the fallow stand (Figure 4) and also for germinants and seedlings in the PUK. The inverse trend was rare and mostly seen for young adults in the fallow stand (Figure 4).

\section{Growth of Seedlings, Saplings And Young Adults}

A preliminary analysis showed that there was no significant difference between types of patch in the forest stand regarding growth variables. Hence the results of the forest stand concerned

Table 2: Density of the natural regeneration of $V$. paradoxa by stand at each time point (year)

\begin{tabular}{lccc}
\hline Stands & \multicolumn{3}{c}{ Mean density $\left(\right.$ ha $\left.^{-1}\right)$} \\
\cline { 2 - 4 } & 2002 & 2003 & 2004 \\
\hline Fallow & $1665^{\mathrm{a}}$ & $1850^{\mathrm{a}}$ & $1710^{\mathrm{a}}$ \\
Forest & $95^{\mathrm{b}}$ & $85^{\mathrm{b}}$ & $76^{\mathrm{b}}$ \\
\hline
\end{tabular}

Table 3: Density of the natural regeneration of $V$. paradoxa by category at each time point (year)

\begin{tabular}{lccc}
\hline Categories & \multicolumn{3}{c}{ Mean density $($ ha-1) } \\
\cline { 2 - 4 } & 2002 & 2003 & 2004 \\
\hline Germinants & $3653^{\mathrm{a}}$ & $4052^{\mathrm{a}}$ & $3706^{\mathrm{a}}$ \\
Seedlings & $94^{\mathrm{b}}$ & $105^{\mathrm{b}}$ & $118^{\mathrm{b}}$ \\
Saplings & $83^{\mathrm{b}}$ & $77^{\mathrm{b}}$ & $78^{\mathrm{b}}$ \\
Young adults & $39^{\mathrm{b}}$ & $28^{\mathrm{b}}$ & $34^{\mathrm{b}}$ \\
\hline
\end{tabular}

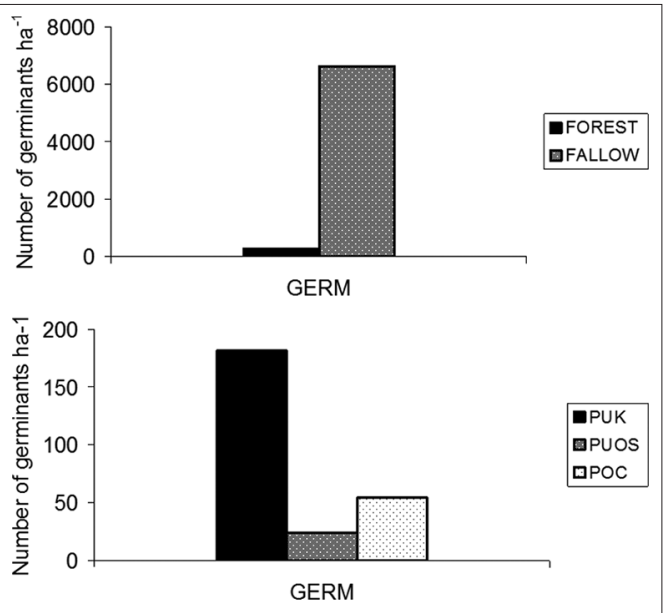

Figure 2: Mean number ha-1 of germinants in the forest and fallow stands (a) and in the types of patch (b) in the forest 
all patches combined. The means of measured variables (height, collar girth and girth at breast height) are shown in Table 4. The fallow stand showed higher means than the forest stand for all regeneration categories except the height of saplings (Table 4). However, a large difference between stands was observed for the mean height of young adults only $(318 \mathrm{~cm}$ vs. $274 \mathrm{~cm}$ for fallow and forest, respectively). For this variable (TH), large standard errors were observed in both stands (11.87 and 13.75; Table 4).

Bonferroni's test on the height growth for comparing stands at each time point (year) was not significant for all regeneration categories (Table 5).

Repeated measures analysis carried out on height growth for each category of regeneration showed a nonsignificant stand effect and a nonsignificant time ${ }^{*}$ stand interaction for all categories. However, the time point (year) effect was significant $(\mathrm{P}<0.0001)$.

\section{DISCUSSION}

\section{Impact of Land Management Mode on The Density of V. Paradoxa Natural Regeneration}

Results from the density study showed that V. paradoxa regenerates in both forest and fallow stands. However, the density of all regeneration categories was high in the fallow stand

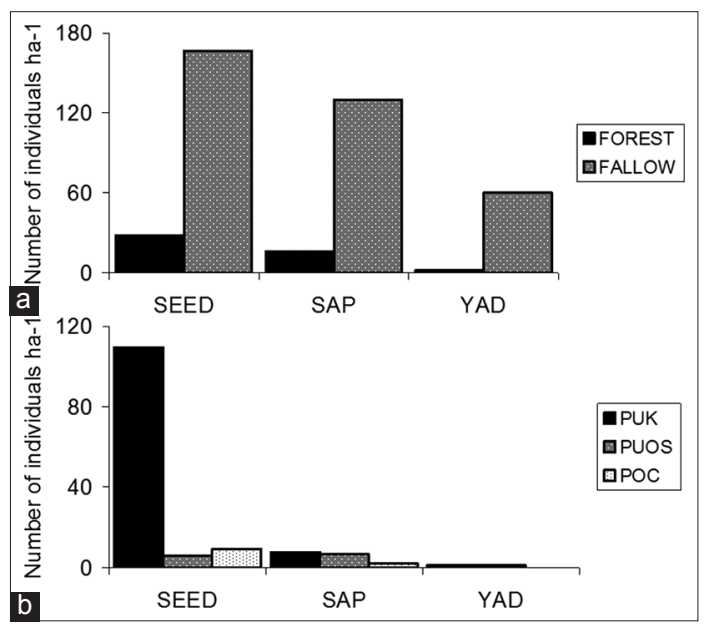

Figure 3: Mean density ha-1 of seedlings, saplings and young adults in the forest and fallow stands (a) and in the types of patch in the forest stand (b)

Table 4: Average of measured variables (total height, collar girth, girth at breast height) by stand and category of regeneration of $V$. paradoxa

\begin{tabular}{lccc}
\hline \multicolumn{4}{c}{ Mean of measured variables } \\
\hline Stands/Categories & TH $(\mathrm{cm})$ & CG $(\mathrm{cm})$ & GBH (cm) \\
\hline FALLOW & & & \\
Seedlings & $74 \pm 2.09$ & $7 \pm 0.27$ & \\
Saplings & $146 \pm 7.70$ & $14 \pm 0.98$ & $8 \pm 0.34$ \\
Young adults & $318 \pm 11.87$ & $24 \pm 0.96$ & $15 \pm 0.73$ \\
FOREST & & & \\
Seedlings & $72 \pm 1.19$ & $6 \pm 0.18$ & \\
Saplings & $152 \pm 4.55$ & $12 \pm 0.40$ & $6 \pm 0.35$ \\
Young adults & $274 \pm 13.75$ & $23 \pm 1.88$ & $13 \pm 0.31$ \\
\hline
\end{tabular}

$\mathrm{TH}=$ total height; $\mathrm{CG}=$ collar girth; $\mathrm{GBH}=$ girth at breast height compared to the forest stand. The difference between stands regarding the mean density was significant $(\mathrm{P}<0.0001)$ and the density of germinants was significantly higher than that of the other regeneration categories. Many scientists have reported similar results for this tree species, stating that the expansion of $\mathrm{V}$. paradoxa is linked to human activities $[16,17]$.

The high density of germinants is proof that V. paradoxa regenerates well. However, there was an alarming drop in the density (99\%) between the stages of germinants and young adults (Table 3). This mortality of the regeneration could be explained by the effects of both human practices (bush fire, cattle grazing) and abiotic factors (drought, soil conditions). For a similar mortality rate, the fallow stand offers the highest density of germinants and therefore the highest number of individuals reaching the adult stage, and the fallow stage therefore appears to be an important and necessary practice for the survival of the species. Elimination and/or shortening of the fallow stage will lead to a major threat, since populations of $\mathrm{V}$. paradoxa are ageing and the regeneration is poor, as noted by Gijsbers et al. [9], Okullo et al. [12].

In both stands, the density varied according to year for most of regeneration categories (germinants, seedlings and young adults), and various trends were observed (Figure 4). These results clearly indicated a high sensitivity of $\mathrm{V}$. paradoxa natural regeneration to environmental conditions, mainly drought, soil, cattle trampling and grazing, as reported by Kelly [14]. In fact, 2003 was an unusual year regarding annual rainfall, which was $>1000 \mathrm{~mm}$ (mean annual rainfall $=850-900 \mathrm{~mm}$ for this site) and allowed abundant germination, as shown by the noticeable increase in density in both stands. The decrease observed in 2004 could be explained by the effects of competition, natural selection, trampling during the dry season (2003-2004) causing a mortality not compensated for by the germination that occurred in 2004.

Very similar results were reported for $\mathrm{V}$. paradoxa by Raebild et al. [18] in southern Burkina Faso. These authors found that seedling densities were higher under tree crowns and in zones where human activities were less intense. For other species like Combretum glutinosum, Piliostigma reticulatum, Terminalia avicennioides, etc., Raebild et al. [18] found that the densities were low in fields but higher in fallows. Byakagaba et al. [19] found that in Uganda, the density of seedlings of $\mathrm{V}$. paradoxa

Table 5: Comparison of stands for height growth for each category of regeneration (Bonferroni's test with univariate analysis at each time point)

\begin{tabular}{lccc}
\hline Categories/Stands & \multicolumn{3}{c}{ Mean height (cm) } \\
\cline { 2 - 4 } & 2002 & 2003 & 2004 \\
\hline Seedlings & & & \\
$\quad$ Fallow & $73^{\mathrm{a}}$ & $78^{\mathrm{a}}$ & $82^{\mathrm{a}}$ \\
$\quad$ Forest & $71^{\mathrm{a}}$ & $76^{\mathrm{a}}$ & $81^{\mathrm{a}}$ \\
Saplings & & & \\
$\quad$ Fallow & $147^{\mathrm{a}}$ & $156^{\mathrm{a}}$ & $162^{\mathrm{a}}$ \\
$\quad$ Forest & $153^{\mathrm{a}}$ & $157^{\mathrm{a}}$ & $156^{\mathrm{a}}$ \\
Young adults & & & \\
$\quad$ Fallow & $329^{\mathrm{a}}$ & $313^{\mathrm{a}}$ & $323^{\mathrm{a}}$ \\
$\quad$ Forest & $265^{\mathrm{a}}$ & $275^{\mathrm{a}}$ & $282^{\mathrm{a}}$ \\
\hline
\end{tabular}




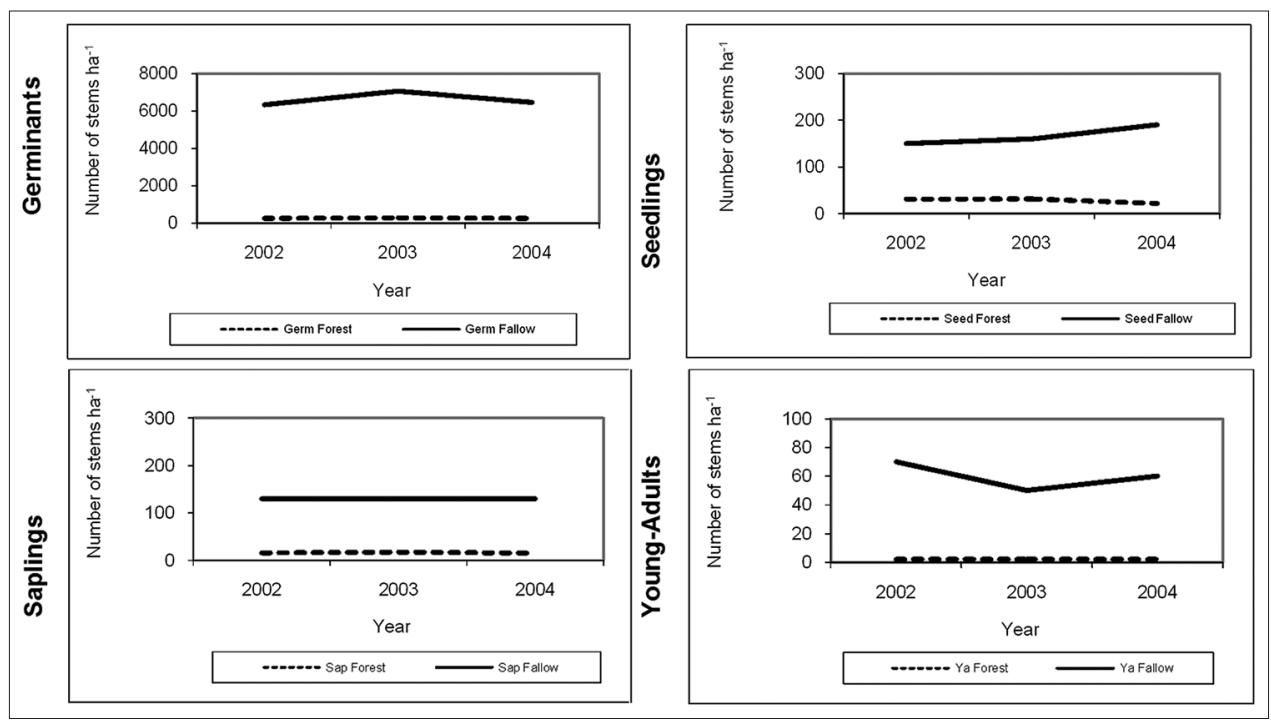

Figure 4: Change in density of germinants, seedlings, saplings and young adults in the stands

subsp nilotica was influenced by land management regime and also young fallows registered high seedling density compared to old fallows and current fields. Aleza et al. [20] reported from their study in Benin that the land management regime had a significant influence on the regeneration of $\mathrm{V}$. paradoxa.

Studies of the natural regeneration of parkland tree species in sub-Saharan African are scarce compared with other regions, mainly temperate zones where the natural regeneration of several forest tree species has been studied. For instance, Saksa [21] observed for Piceas abies (L) Karst a variation of the emergence of germinants between monitoring plots strongly correlated with seed crop of the same year. This author explained the observed variation by weather conditions. Similar results were reported by de Chantal [22], Lähde [23], Valkonen [24] for other temperate tree species.

\section{Impact of Land Management Mode on Height Growth of V. Paradoxa Natural Regeneration}

An overall analysis of height growth for all regeneration categories combined showed a highly significant difference between the stands $(\mathrm{P}=0.000)$. However, when data were analysed according to each category, the difference between stands was significant for young adults only $(\mathrm{P}=0.022)$ and the fallow stand registered high mean height $(318 \mathrm{~cm})$ compared to the forest stand $(274 \mathrm{~cm})$.

Annual height increase was low and almost similar in the two stands for the different regeneration categories $(3.92 \mathrm{~cm}$, $5.63 \mathrm{~cm}$, and $14.6 \mathrm{~cm}$ in the fallow stand and $5.72 \mathrm{~cm}, 4.84 \mathrm{~cm}$ and $10.33 \mathrm{~cm}$ in the forest stand for seedlings, saplings and young adults, respectively). This result contrasts with what was observed for the density and suggests that, independently to the land use regime, V. paradoxa natural regeneration is subject to events affecting its growth. These events are competition for light and nutrients and other human practices (bush fire, cattle grazing) occurring in both stands.
The observed annual height increase suggests that $\mathrm{V}$. paradoxa grows slowly and this slow growth explains the weak transition between categories: seedling to sapling, sapling to young adult stages, noted by Kelly [14].

Slow growth of $\mathrm{V}$. paradoxa was observed in the nursery as well as in the field after transplanting. Yakubu et al. [25] found that values of shoot height of V. paradoxa for different levels of mineral fertiliser ranged from 8.49 to $10.64 \mathrm{~cm}$ sixteen weeks after transplantation in the greenhouse of the Forestry Research Institute of Nigeria, Ibadan. They reported that application of NPK did not have a significant effect on the growth of V. paradoxa seedlings. Agele et al. [26] also observed similar slow growth 6 months after transplanting, but found a significant difference between treatments. Their results shown that shea butter seedlings treated with two tonnes ha-1 of manure in combination with watering either once a week or every two weeks exhibited significantly $(\mathrm{p}<0.05)$ better growth than seedlings from the other treatments.

Despite the low growth we observed in both stands, the results suggest that the fallow stand offers a better chance to newly emergent plants of reaching the adult stage. Our findings strengthen the statement of Serpantier [17], i.e. the link of V. paradoxa expansion to human activities, mainly to the field/ fallow cycle.

The effect of the land-use system was observed for other tree species also. In comparing the mean height between land-use systems, Nacoulma et al. [27] found a significantly greater height in the protected area than in the parkland for seedlings and saplings of Afzelia africana and Pterocarpus erinaceus in eastern Burkina Faso.

\section{CONCLUSION}

The results of our study show that $\mathrm{V}$. paradoxa regenerates naturally. However, establishment and growth of the regeneration 
appear to be affected by several factors. Many aspects, like spatial distribution, density and growth are affected by the conjunction of human practices and natural forces. The high mortality rate observed during the growth of the regeneration could be explained by these factors. Due to this mortality, few young adults were obtained from the huge number of germinants, which is evidence for the threat regarding the renewal of the ageing population of $\mathrm{V}$. paradoxa.

Regarding the land management effect, both fallow and forest stands allow regeneration to emerge and grow, but the fallow stand offers better conditions of survival and growth. The patches in the forest stand have little impact on growth parameters and it is important to point out that they very likely result from the mode of seed dispersal.

The monitoring period (three years) was a bit short to obtain long-term features of the effect of human practices on the natural regeneration of $\mathrm{V}$. paradoxa. However, these first results offer good insight into the ability of this parkland tree species to regenerate naturally and the possible effects of the land management regime in conjunction with time and other environmental factors. Our study also shows that it is still possible to overcome the threats regarding the lack of regeneration in fields, for instance, because the species regenerates very well naturally. Hence, by taking very easy actions, such as training and informing farmers, making them aware of the necessity to save some young $\mathrm{V}$. paradoxa plants during ploughing and observing an optimal fallow period, the survival of the species will be achieved. Finally, based on our findings (the high ability to regenerate naturally) and considering the increasing interest in the species, we can state that $\mathrm{V}$. paradoxa is not at present an endangered species.

\section{ACKNOWLEDGEMENTS}

This work was undertaken in the framework of a PhD study funded by the EU and Cirad (France). We are very grateful to them for their financial assistance. We also want to thank the head staff of IER (Mali) and all colleagues who participated in field work for the good working environment and logistical support. Finally, we would like to express our gratitude to the farmers of the study site (Mperesso) who collaborated and allowed us to carry out our research activities on their land.

\section{REFERENCES}

1. Larocque G. Regeneration in a tolerant harwood stand managed under single-tree selection. Information report pi-x-50. Petawa national forestry institute. Canada. Med. 1985;(71)-17

2. Ballabha R., Tiwari J.K., Tiwari P. Regeneration of tree species in the sub-tropical forest of Alaknanda Valley, Garhwal Himalaya, India. Forest Science and Practice 2013;15:89-97.

3. Bhakuni N., Kapkoti B., Lodhiyal N. Quantitative analysis and regeneration status of Ghorakhal forest in Nainital of Kumaun Himalaya. International Journal of Basic and Life Sciences 2015;3:1-6.

4. Busing R.T. Canopy cover and tree regeneration in old-growth cove forests of the Appalachian Mountains. Vegetatio 1994:115: 19-27.

5. Sushma S., Zubair A. M., Chandra M. S. Tree species richness, diversity, and regeneration status in different oak (Quercus spp.) Dominated forests of Garhwal Himalaya. India Journal of Asia-Pacific Biodiversity 2016;9:293-300

6. Nair P. K. R. An introduction to agroforestry. Kluwer Academic
Publishers, Dordrecht, the Netherlands 1993;499 pp.

7. Raison J. P. Les "parcs" en afrique: etat des connaissances et perspectives de recherche. Document de travail. Paris, France, Centre d'Etudes Africaines EHESS 1988;117 pp.

8. Teklehaimanot Z. Exploiting the potential of indigenuous agroforesrty trees: parkia biglobosa and vitellaria paraoxa in Sub-saharan Africa. Agroforestry systems 2004;61,207-220.

9. Gijsbers H. J. M. Kessler J. J. and Knevel M. K. Dynamics and natural regeneration of woody speciesin farmed parkland in the sahel region (province of passoré) Burkina Faso. Forest ecology and management1994;64:1-12.

10. Kelly B., Bouvet J. M. and Picard N. Size class distribution and spatial pattern of vitellaria paradoxa in relation to farmers' practices in mali. Agroforestry systems 2004;60:3-11.

11. Nikiema A., Van der Maesen, L. J. G. an Hall, J. B. The impact of parkland management practices on plant resources diversity pp 43-50. In: Teklehaimanot Z. (ed.), improved management of agroforestry parkland systems in sub-saharan africa. Eu/inco project contract ic18-ct98-0261, final report, university of wales bangor, UK 2003.

12. Okullo J. B., Hall J. B. and Masters E. Reproductive biology and breeding systems of Vitellaria paradoxa. pp. 66-84. In: Teklehaimanot Z. (ed.), improved management of agroforestry parkland systems in sub-saharan africa. Eu/inco project contract ic18-ct98-0261, final report, university of Wales Bangor, UK 2003.

13. Hall J. B. Aebischer D. P. Tomlinson H. F. Osei-amaning E. and Hindle J. R. Vitellaria paradoxa: A Monograph. School of agricultural and forest sciences, University of Wales Bangor, UK 1996;105 pp.

14. Kelly B. A. Impact des pratiques humaines sur la dynamique des populations et sur la diversité génétique de Vitellaria paradoxa (karité) dans les systèmes agroforestiers au sud du mali. Thèse de doctorat. Université de Bamako 2005;243 pp.

15. Morrison D. F. Multivariate Statistical Methods, New York: McGrawHill 1990.

16. Pélissier P. L'arbre dans les paysages agraires de l'afrique noire. Cahiers ORSTOM, Série Sciences Humaines 1980:17(3 et 4):131-136.

17. Serpantier G. Rôles des jachères dans la production arborée non ligneuse en savane soudanienne. Cas du karité dans l'ouest du burkina faso. In c. Floret (ed.) Actes de l'atelier la jachère, lieu de production, 55-57, Bobo Dioulasso 1996.

18. Ræbild A., Hansen U. B., Kambou S. Regeneration of Vitellaria paradoxa and Parkia biglobosa in a parkland in southern Burkina Faso. Agroforest Syst. 2011; doi 10.1007/s10457-011-9397-0

19. Byakagaba P., Eilu G., Okullo J.B.L., Tumwebaze S.B. and Mwavu E.N. Population structure and regeneration statut of Vitellaria paradoxa (C.F.Gaertn.) under different land management regimes in Uganda. Agricultural Journal 2011;6 (1):14-22.

20. Aleza K., Wala K., Bayala J., Villamor G. B., Dourma M., Atakpama W. Akpagana K. Population structure and regeneration status of Vitellaria Paradoxa (C. F. Gaertner) under different land management regimes in Atacora department, Benin. Agrofrest Syst. 2015;DOI 10.1007/ s10457-015-9787-9.

21. Saksa T. Regeneration process from seed crop to saplings - a case study in uneven-aged Norway spruce - dominated stands in southern Finland. Silva Fennica 2004;38(4):371-381.

22. De chantal M. The effects of site and soil properties on the establishment and early development of pinus sylvestris and picea abies regenerated from seeds. University of Helsinki Department of Forest Ecology Publications 27 2003;36 p.

23. Lähde E. Natural regeneration of all-sized spruce-dominated stands treated by single tree selection. In: hagner, $n$ (ed.). Silvicultural alternatives. Proceedings from an internordic workshop, umea, sweden, june 22-25, 1992. Swedish University of Agricultural Sciences, Department of Silviculture, Reports 1992;35:117-123

24. Valkonen S. Regeneration models for Norway spruce stands being developed towards all-aged structures. In: skovsgaard jp \& johannsen vk (eds.). Modelling regeneration success and early growth of forest stands. Proceedings from the IUFRO conference, held in Copenhagen, 10-13 june 1996;166-175.

25. Yakubu F.B., Asinwa I.O., Shodeke D.K.A., Williams O.A. and Obekpa N.B. Effects of NPK fertilizer on the shoot growth of Vitellaria paradoxa C.F. Gaertn. African Journal of Environmental Science and Technology. 2015; Vol 9(1):8-11.

26. Agele S.O., Osaigbovo A.U., Ogedegbe S.A. and Nwawe A.K. Effects of watering regime, organic manuring and mycorrhizal inoculation on the growth and development of Shea butter Vitellaria paradoxa C.F.Gaertn) seedlings. International Journal of Agricultural Policy and Research 2016:Vol.4 (3):35-45.

27. Nacoulma B. M. I., Traoré S., Hahn K. and Thiombiano A. Impact of land use types on population structure and extent of bark and foliage harvest of Afzelia africana and Pterocarpus erinaceus in Eastern Burkina Faso. International Journal of Biodiversity and Conservation 2011; Vol.3(3):62-72 